\title{
Development of Biodiversity Scopes from Nature Conservation to the Community Centralization - Cement Tonasa Manufacturing, Indonesia
}

\author{
Dewi Permatasari, James Pinem, Syaifullah, Bambang Haryanto, Subhan, and Sariatun
}

\begin{abstract}
Biodiversity Conservation is one of requirement for the reclamation plan of post-mining area of limestone as one of raw material extraction for cement manufacturing. Previous publication of Semen Tonasa Creating Shared Value conception has been developed from single biodiversity aspect into community centralization within integration to energy efficiency and best environmental practice. Geopark Bulu Sipong, as one of historical biodiversity conservation that has been initiated for several years are still became ongoing activity based on strategic planning.

This paper mainly discuss about the conservation and community activities of Cement Tonasa. Collaboration among of these activities has added value in resulting economic beneficiaries to improve community welfare. There is also environmental and social benefit as positive impacts of the scopes development. Main goals of program development are to support and contribute to the global Sustainable Development Goals (SDGs): in terms of Decent Work and Economic Growth $\left(8^{\text {th }}\right)$, Life on Land $\left(15^{\text {th }}\right)$, and Partnership for the Goals $\left(17^{\text {th }}\right)$.

The progress result for the first quarter-year of 2019 is the development of partnership, program and activity planning, and also economic valuation. Partnership development both internal and external, are mainly collaboration between divisions or agencies to achieve the goals. We conclude that collaboration between industry, stakeholders, and local community will bring sustainable improvement to the environment. Also, economic activity has improved $70 \%$ of average income compared to regional standard. This is a good starting point to achieve sustainability to the surrounding environment even without industrial activity in the future.
\end{abstract}

Index Terms-Biodiversity conservation, cement Tonasa manufacturing, Indonesia, community activities, economic valuation, energy efficiency, environmental practice, and sustainable development goals.

\section{INTRODUCTION}

Cement Tonasa Manufacturing, is one of national cement industry in Indonesia, situated in Pangkajene and Kepulauan (known as: Pangkep) District, South Sulawesi Province. Previous publication [1] has explained a summary of Cement Tonasa manufacturing in a progress of creating shared value to surrounding community. This paper will focus to one of Cement Tonasa initiative towards development of biodiversity scopes of conservation from single nature

Manuscript received September 12, 2019; revised January 5, 2020

Dewi Permatasari is with Environmental Professional - Renewable and Non-Renewable Energy, Indonesia.

James Pinem, Syaifullah, Bambang Haryanto, Subhan, and Sariatun are with PT Semen Indonesia Tbk, Indonesia (e-mail: syaifullah@semenindonesia.com). conservation to community centralization.

Geopark Bulu Sipong, the second biggest Geopark in the World, is become a center of archeological and biodiversity conservation which located in Cement Tonasa operational area. This program has been successfully implemented for several years, which also awarded as one of cultural heritage sites. In addition, this program has a concept development with the integration to local community. It is also combined with energy conservation and environmental best practice to complete the integration of all sustainability aspects.

This program shows the supports and contributions to Global Sustainable Development Goals (SDGs) in certain criteria as mentioned. Quarter-year of 2019 progress will also be discussed. The linkages between Environmental Compliance and beyond (known as PROPER) and Life Cycle Inventory will also discuss as part of environmental trends nowadays.

\section{OVERVIEW OF ENVIRONMENTAL COMPLIANCE AND BEYOND FOR INDUSTRIAL SECTOR IN INDONESIA}

PROPER (an abbreviation of Program Penilaian Peringkat Kinerja Perusahaan dalam Pengelolaan Lingkungan Hidup) is one of Indonesian Government program assessed and awarded by the Indonesian Minister of Environment and Forestry periodically to the industries that applied compliance and/ or beyond compliance activity besides doing industrial process. There are criteria and steps of PROPER assessment, based on current regulation of the Indonesian Minister of Environment and Forestry 03/ 2014 [2] and its adaptation, as discussed below.

- Preparation; is the very first step, consists of time series data collection, lesson learned from the best practice of companies based on previous PROPER result, and program inventory. Industries also have to update their basic company information such as profile, numbers of employee, and production and installed capacity.

- Compliance Assessment; where every participant of the industry should report basic environmental document and its monitoring data. There are several environmental aspects for Cement Manufacturing sector such as water and air pollution control including ambience and continuous monitoring, hazardous waste management and permitting, environmental permits (EIA, sub-EIA, etc.), environmental management system (new adaptation criteria since 2019), and land rehabilitation criteria (for Cement Industry whom also operates limestone and/ or clay mining for its raw material). This step delivers the 
results of percentage which divided into Comply (Blue Ranking), Near Comply (Red Ranking), and Not Comply (Black Ranking).

- Beyond Compliance Assessment; the candidates of this step were chosen based on results of compliance percentage. Only participants regarded as $\mathbf{1 0 0 \%}$ Compliance will be invited to propose PROPER beyond compliance in certain criteria. There are several aspects assessed: the Summary of Environmental Performances, Life Cycle Assessment (a new adaptation in 2019 criteria, replacing Environmental Management System that became compliance criteria), Energy Efficiency, Hazardous Waste Management, Solid Waste Management, Emission Reduction, Water Efficiency, Wastewater Management, Biodiversity Protection, and also Community Development (a CSR non-charity paradigm). Results on this step delivered as $\mathbf{2 5 \%}$ bottom percentile (back in Blue Ranking), in between $25 \%$ to $75 \%$ percentile (Green Ranking), and $\mathbf{2 5 \%}$ highest percentile (promoted to the Gold Assessment - latest known as Grold Candidate).

- Gold Assessment; the last but the hardest step to be assessed. Only the top $25 \%$ per sector can be promoted. There is also consideration of environmental consistency as in PROPER required at least twice Green Ranking in a row of previous periodical assessment (last 2 years). The chosen candidates will present their willingness and innovative way of thinking including awareness to the local community, and if necessary, there will be field verification to make sure the effectiveness of each program. This step delivers Gold Ranking and Green Ranking (if does not meet Gold Standard of the year).

Cement Tonasa, as any other Cement Manufacturing industry, has a goal to achieve environmental excellence both in business process and also for its surrounding community and environment. Not only in participation to government initiative, but also for becoming a role model in the industry, mainly as part of East Indonesia Region that contributes to national development.

\section{LIFE CYCLE INVENTORY}

Starting in year of 2019, Cement Tonasa is ongoing to analyze the life cycle inventory for its product. The goal is to perceive best case scenario of cement production and packaging system. It also aimed to support environmental trends for industrial sector in contributing to the national program. Functional unit of cement life cycle is ton cement, within a boundary as cradle to gate [3]. The initial life cycle inventory of Cement Tonasa shows in Table I.

TABLE I: LIFE CYCLE INVENTORY OF CEMENT TONASA

\begin{tabular}{|c|c|c|}
\hline \multirow{2}{*}{ No } & \multicolumn{2}{|c|}{ Input of Activity } \\
\cline { 3 - 3 } & Activity & Sub-Activity \\
\hline \multirow{2}{*}{1} & Raw Material & Limestone and Clay Mining \\
\hline \multirow{2}{*}{2} & \multirow{2}{*}{$\begin{array}{c}\text { Blending \& } \\
\text { Clinkerization }\end{array}$} & Raw mill \\
\cline { 3 - 3 } & & Pre Heater \\
\cline { 3 - 3 } & & Kiln \& Cooler \\
\hline 3 & Grinding \& Packing & Coal Mill \\
\cline { 3 - 3 } & & \multicolumn{2}{|c|}{ Panish Mill } \\
\hline
\end{tabular}

In the early stage, analysis has been done for 3 main impact categories [3]; consist of green-house gases, eutrophication, and acidification. Life Cycle Inventory, however, is not directly connected to biodiversity conservation, somehow the best scenario in cement production will reduce operational cost, which positively impacted to biodiversity integration program based energy and environmental point of view. Results and details will be discussed in further publication.

\section{RESULTS AND DISCUSSIONS}

\section{A. Biodiversity Conservation and Development}

The center of program discussed in this paper is biodiversity conservation and its development throughout periodical monitoring activity. Biodiversity itself represents as Geopark Bulu Sipong conservation (see Fig. 1), which have many positive and potential impacts in some energy, environment, and community development aspects. This program also contains its novelty, which the biggest Geopark heritage site in Indonesia and the second biggest in the world after China.

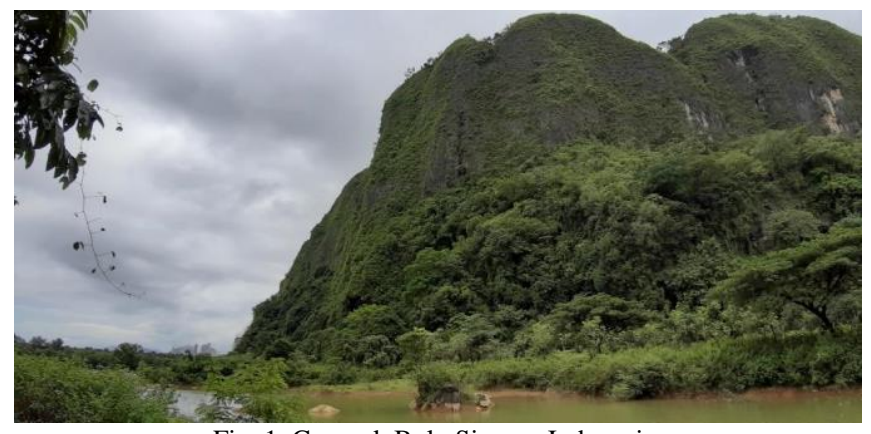

Fig. 1. Geopark Bulu Sipong, Indonesia.

According to National Geopark Committee in Indonesia, Geopark Bulu Sipong has been considered as one of Cultural Heritage Sites [4]. It is suggested to develop its heritage potential in many areas of improvement and integration to related aspect. Firstly, Geopark itself has to finish baseline study to acknowledge current item discovered. It was found out that Geopark have 9 archeological sites, study has been done by Cultural Preservation Center of Makassar (2017); Archeologists of Hasanuddin University, Griffith University Australia and Wolonggong University of Australia (2018) $[5]$.

Secondly, Geopark has to become center of prehistory that represents ancient archeological in East Indonesia Region. This has been continuously visited by university worldwide (even abroad) to do research and findings about its archeological uniqueness.

Thirdly, which discussed in points below is the development and improvement of Geopark within integration to strategic aspects, such as Community Development, Energy Conservation and Emission Reduction, and Water Efficiency. Implementation of this program has inspired other operational unit in Cement Tonasa to starting utilize environmental potential based community development as discussed below.

For future improvement, Cement Tonasa has also goals to increase tourism activity by also considering the surrounding 
environment. This will bring 3 main objectives, which consist of community, tourism, and nature conservation.

\section{B. Integration to Community Development}

Activity in Geopark Bulu Sipong (latest will be named as Geosite Maros Pangkep), has been increased since many archeologists and researchers found artifacts during 2017-2018. This attracts prehistoric tourism and thus drives local community to have opportunity in economic improvement. The activity and findings of artifacts is then depicted in Fig. 2.

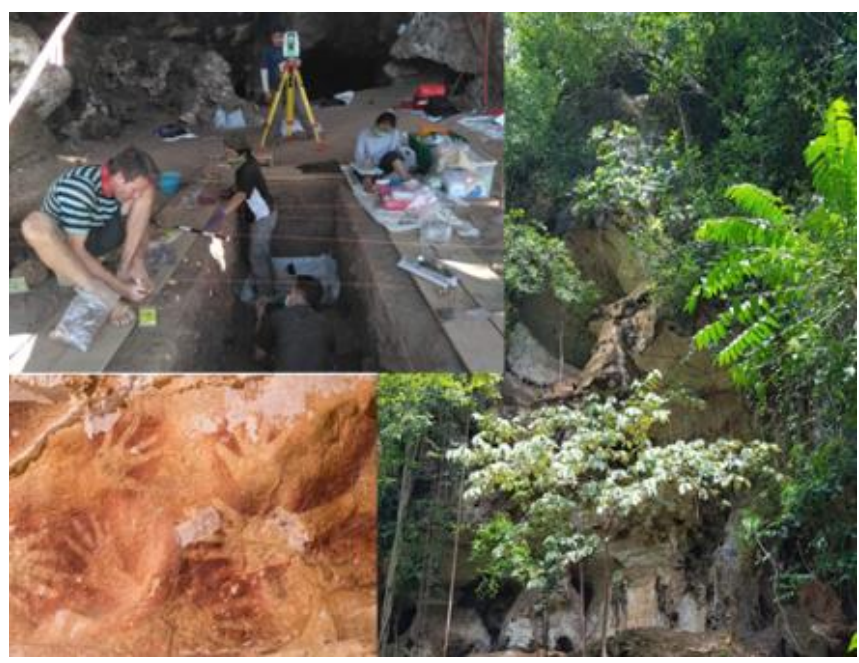

Fig. 2. Activity in Geopark Bulu Sipong through educative and prehistoric tourism.

Geopark Bulu Sipong development has been awarded and considered as breakthrough innovation in Cement Indonesia Innovation Award in 2018. In terms of welfares improvement of local community, two local actors have been empowered within $15-20 \%$ economic enhancement [6]. Moreover, since 2018 it was found out that tourism visitation in Geopark has been reached over 400 goers. This program considered successful in implementation since it has able to attract tourism potential in Pangkep District.

\section{Program Based Energy Efficiency}

Geopark Bulu Sipong is ongoing to be improved on renewable energy utilization using solar panel. This program has objective to reduce electricity consumption, mainly for lighting, in Geopark area. Location candidate for solar panel installation is then depicted in Fig. 3.

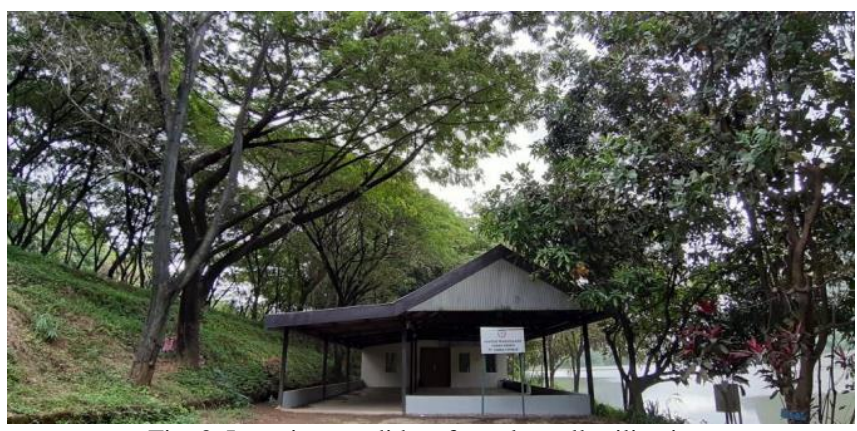

Fig. 3. Location candidate for solar cell utilization.

This program calculated to be able to reduce electricity consumption about $1,825 \mathrm{kWh}$ per year [7]. With a linear utilization of solar panel, for the next twenty years, total calculated saving of energy consumption is $36,500 \mathrm{kWh}$ by using about 11 solar panel units.

As for green-cost perspective, cost for installation and maintenance are not discussed in this paper. Due to the only concern is to bring environmental point of view to the program implementation.

\section{Positive Impact to Emission Reduction}

Geopark access road also situated in reclamation area, which in Cement Tonasa, it almost fulfill successful parameter of good reclamation. To see the reclamation area for Geopark access road is shown in Fig. 4.

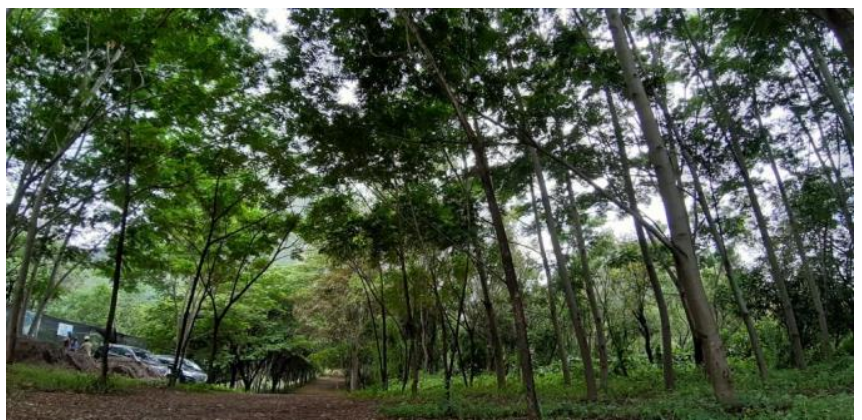

Fig. 4. Geopark access road in reclamation and re-vegetation area of cement Tonasa post mining activity.

Solar cell utilization, as mentioned above, directly drives positive impact on its carbon footprint due to electricity consumption. Therefore, emission released to the atmosphere by this activity will also be reduced. It has been calculated that 0.095 ton $\mathrm{CO} 2$-eq per $\mathrm{kWh}$ of emission will potentially reduce, which 30x less emission than current electricity source in Geopark lighting generated by Coal-Fired Power Plant of Biringkassi [8].

\section{E. Water Conservation: Rain Water Utilization for Fishery Activity}

Geopark Bulu Sipong is surrounded by post-mining area of Cement Tonasa, both clay and limestone. Based on compliance of post-mining activity regulation in Indonesia, there should be reclamation and re-vegetation on post-mining land. This somehow drives water conservation alongside the Geopark location.

The purpose of the program is to utilize rain water to fill the post-mining pond, which deliver fishery activity based on best available water source. The reclamation activity for fishery is depicted in Fig. 5.

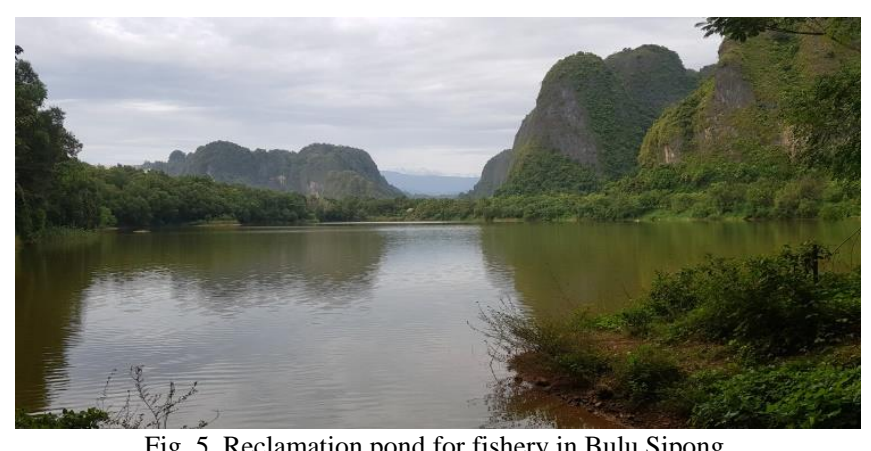

This program has been implemented for more than 7 years, with total measured fishery pond about $23,000 \mathrm{~m}^{2}$ and conserved rain water about more than $115,000 \mathrm{~m}^{3}$ [9]. By the 
implementation of this program, about 40 local heroes have been empowered. In terms of economic positive impact, this program has improved local community income up to $70 \%$ based on regional standard. This calculation based on monthly average of income per each member of local community. While regional standard is refer to Regional Standard of Pangkajene and Kepulauan District.

However, the water used only recommend for fishery activity only, whereas for drinking water, local community are using conventional way. Thus, many improvements in the future for Geopark management are also becoming one of our concerns.

\section{F. Other Community Based Program}

Besides discussing about Geopark scopes development, this paper also share some of other program in community based. The location of program is not located in Geopark area, though the basic fundamental of program implementation has adapted the same principal.

\section{Progress of Bank of Waste: Women Empowerment}

As part of sustainability commitment in reducing and utilizing waste of bottle plastic, Bank of Waste of Cement Tonasa is a starter program, run by women empowerment surrounding cement plant area. This program is a transition to tumbler usage to gradually replace habits of using plastic bottles in the community. Hopefully in five continuous years, there will be zero plastic usage in the area. Thus, activity of women empowerment in Cement Tonasa plant area is depicted in Fig. 6.

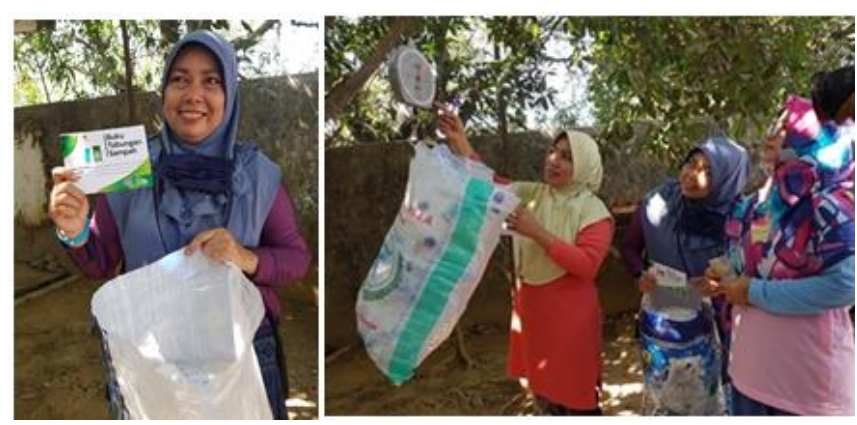

Fig. 6. Women empowerment activity in bank of plastic waste.

About 50 plastic bottle wastes per day have been managed, within the integration to tumbler campaign in plant area, only $50 \%$ of plastic bottle waste allowed in this period [10]. We aware that it's never been easy to change paradigm instantly, thus conducting periodical monitoring and support from related stakeholders the program has a huge possibility to succeed.

Wastewater Management in Coal-Fired Power Plant of Biringkassi: Introduction to Community-Based

Cement Tonasa, in operating their Cement Production Facility, does require amounts of electricity. Electricity generation also generates by utilizing Coal-Fired Power Plant, located in Biringkassi sub-District. Surrounding the Power Plant Facility, there is a lot of community activity which have development potential, such as salt pond, mangrove, rice fields, etc.

Starting year of 2019, Cement Tonasa is ongoing to prepare community-based program for salt-farmer around power plant area (see Fig. 7-8).

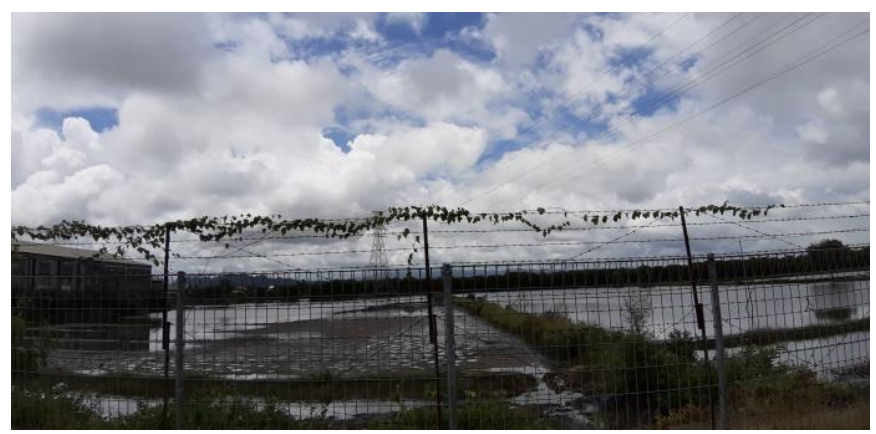

Fig. 7. Salt-pond by the side of Biringkassi power plant.

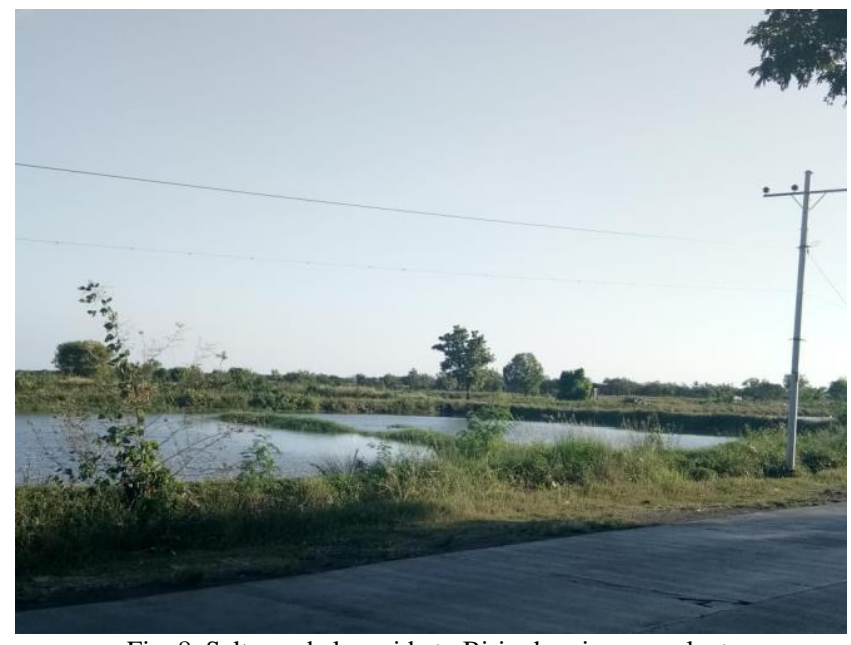

Fig. 8. Salt-pond alongside to Biringkassi power plant

The strategic idea of the program is to utilize power plant effluent wastewater for water source for salt-pond. Preliminary calculation of the program is able to utilize effluent water [11] about $4,700 \mathrm{~m}^{3}$ per day (consist of effluent treated cooling water and treated desalination water). Positive impact of this program is to reduce wastewater load to the stream by utilizing its potential. However, this idea has not been implemented, since it is required technical and feasibility assessment of other impacts. We hope for further publication, this potential will introduce any progress.

\section{G. Future Improvement Hazardous Waste Management}

In this section, there is also preliminary introduction about possible further publication in terms of cement industry innovation to reduce hazardous material consumption. Program is not directly connected to the Geopark, but the value saving from this program possibly able to improve the Geopark development. Waste management on hazardous waste as mentioned is discussed below.

\section{Reclaiming of Lubricant Oil in Use to the Power} Transformer

Reclaiming or also known as regeneration of insulating oil is the process of removal of contaminants and product of degradation such as polar, acidic or colloidal material, as determined by oil and transformer test [12]. In this case is lubricant oil in use to the power transformer of Tonasa $2 / 3$ and Boiler Turbine Generator of Biringkassi. This program is actually part of hazardous waste management to reduce and reuse isolating oil in order to enhance lifetime of power transformer. It is used Silica $\mathrm{Gel}\left(\mathrm{SiO}_{2}\right)$ and Active Alumina $\left(\mathrm{Al}_{2} \mathrm{O} 3\right)$ to enhance the process. Oil transformer as a product of reclaiming in Cement Tonasa operations is depicted in Fig. 8. 


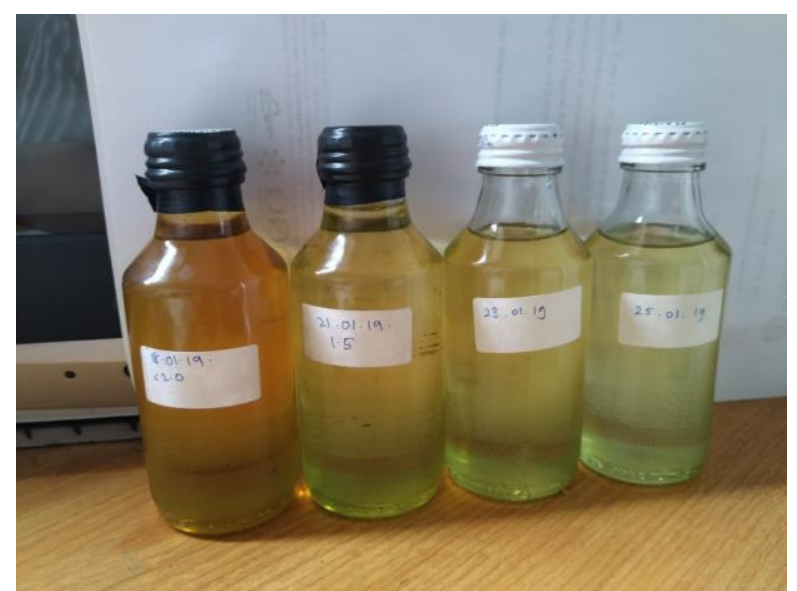

Fig. 8. The re-use of reclaimed oil transformer.

Having been implemented since 2017, this program has been utilized about 40 cubic-meters of reclaimed oil [12]. In the future, this program is considered to be applied in overall feasible location as part of hazardous waste management and optimization.

\section{CONCLUSIONS AND RECOMMENDATIONS}

We conclude that improvement of each activity in operation area, not only technically, but also community-based will bring sustainability together in the future. Thus, periodical monitoring and evaluation required to measure environmental trends and effects of the program implementation. This has been reflected to the 7 (seven) beyond compliance program as stated.

By considering that factory operation is not for lifetime, but the environment and its surrounding living entity has to be viable for lifetime of our future generation. Every industry should keep innovating in many possible aspects to reduce fresh resource usage. Life cycle assessment, in this case also will become new trends in environmental beyond compliance in Indonesia, so that we recommend beginning life cycle thinking starting from material extraction and it's alongside process to the product delivery.

\section{CONFLICT OF INTEREST}

The authors declare no conflict of interest for program implementation. It is purely based on magnitude of environmental and social impact surrounding Cement Tonasa operational area.

\section{AUTHORS CONTRIBUTION}

All the authors also contributed for the completion of paper writing, consist of Main Author (Dewi Permatasari, ST., MT.) who develop the main writing and selection of best practice on environmental management, $2^{\text {nd }}$ Author (Ir James Pinem) who managed environmental management team in Cement Tonasa Manufacturing, $3^{\text {rd }}$ Author (Ir Syaifullah) who prepared for paper presentation to the conference, $4^{\text {th }}$ Author (Ir Bambang Haryanto) who support the paper writing along with supervise the entire division related to production and post-production management in Cement Tonasa Manufacturing, $5^{\text {th }}$ Author (Subhan Ak, MM) for giving the optimum support for the industry to keep balance its operation and socio-environmental management, and also $6^{\text {th }}$ Author (Ir Sariatun, MM) who conducted the research throughout program implementation.

\section{ACKNOWLEDGEMENTS}

The main author would like to express many thanks for huge support from Bapak Bambang Haryanto as Production Director, Bapak Syaifullah for the efforts to create good presentation of the conference, and Ibu Sariatun for time to time support in environmental management in Cement Tonasa Manufacturing. We would like to thanks to all working team member of Cement Tonasa Manufacturing for the continuous spirit in innovation. We also enhance our gratitude to local community and stakeholders for their cooperation and support towards company vision in bringing sustainability to surround living environment.

\section{REFERENCES}

[1] D. Permatasari et al., "Environmental and energy efficiency efforts along with creating shared value to the community: An initiative from manufacturing industry of cement Tonasa, Pangkep - South Sulawesi, Indonesia," presented at International Conference on Environment and Natural Science, Seoul, South Korea, October 2018, International Journal of Advances in Science, Engineering and Technology (IJASEAT), vol. 7, issue 1.

[2] Anonymous, "Peraturan Menteri Lingkungan Hidup Nomor 03 Tahun 2014 Tentang Program Penilaian Peringkat Kinerja Perusahaan dalam Pengelolaan Lingkungan Hidup," Ministry of Environment Law and Regulation, Jakarta, Indonesia, 2014.

[3] S. A. Rewah et al., "Preliminary life cycle inventory of cement Tonasa manufacturing," Internal Report, March 2019.

[4] Anonymous, "Conservation and management of cultural heritage sites of Bulu Sippong, Pangkep — Indonesia," Directorate General of Culture, Ministry of Education and Culture, Indonesia, 2018.

[5] R. Prayudyaningsih et al., "Report of location and vegetation survey in Bulu Sipong heritage site for biodiversity baseline in cement Tonasa manufacturing," Internal Report, May 2018.

[6] M. Yasin et al., "Establishment of biodiversity park, geopark, and pre-historical site in Bulu Sipong," Internal Report, September 2018.

[7] Iswahyudi, R. Purnomo, M. Yasin, and Syaifullah, "Solar cell utilization for supporting geopark activity in Bulu Sipong," Internal Report, May 2019.

[8] Iswahyudi, R. Purnomo, and M. Yasin, "Emission reduction pre-calculation for solar cell installation in Bulu Sipong," Internal Report, May 2019.

[9] Syaifullah, M. Yasin, and H. M. Ilyas, "Reclamation and community development in Bontoa Post-Mining Area," Internal Report, February 2019.

[10] Suroso et al., "Bank of waste women empowerment surrounding cement Tonasa area," Internal Report, Unpublished, June 2019.

[11] Z. Arifin et al., "Study of coal-fired effluent wastewater in biringkassi for salt-embankment potential," Internal Report, June 2019.

[12] M. R. Belli et al., "Oil reclamation to reuse in power transformer of tonasa 2/3 and boiler turbine generator of biringkassi," Internal Report, May 2019

Copyright (C) 2020 by the authors. This is an open access article distributed under the Creative Commons Attribution License which permits unrestricted use, distribution, and reproduction in any medium, provided the original work is properly cited (CC BY 4.0).

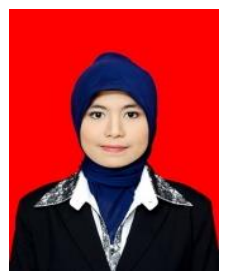

Dewi Permatasari is environmental professional with field of expertise in strategic planning and environmental capacity building within eight years circle of experiences. Dewi also an individual member of Life Cycle Initiative - UN Environment; other than that Dewi also experienced GHG/ CDM Technical Expert for UNFCCC. Dewi is one of the best environmental youth-expert, about 50 industries has been visited, mostly joined her Workshop of Capacity Building, Dewi has been experiencing as Advisor in power generation industries for half-decade, within various of power generation type, such as Geothermal Power Plant, 
Gas-Steam Combined-Cycle Power Plant, Coal-Fired Power Plant, Diesel-Gas Power Plant, and Gas-Fired Power Plant for all over Jawa and Bali Island, both national and multi-national company. Dewi has very well education and experience in environmental problem solving throughout her communication and capacity building skills. To date, Dewi has supported various industries to develop personnel confidence and knowledge in spreading environmental spirit and sustainable commitment, such as Strategic Industries (Aerospace Manufacturing, Defense Equipment Manufacturing, Coal Mining, Mineral Mining (including Smelter and Hydro-Power Utilities), Cement Industry (including isolated Coal-Fired Power Generation support), and also Building Management such as 5-Star Hotels, Apartment, and Office Tower.

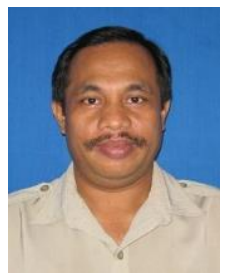

Ir. James Pinem was born in Tigalingga, on October 18 , 1964. He is currently senior manager of Safety, Health and Environment in Cement Tonasa Manufacturing under Semen Indonesia Holding Company. Pinem has joined Cement Industry since year of 1992 throughout various position histories, such as Project Control Senior Officer, Head of Plant Metering and Controlling Strategic, Senior Manager of Plan Administration and Procurement Monitoring, etc. Pinem graduated from University of Pasundan, Bandung - Indonesia in 1983. In 2017, Pinem has awarded a $25^{\text {th }}$ Years of Dedication in Cement Industry.

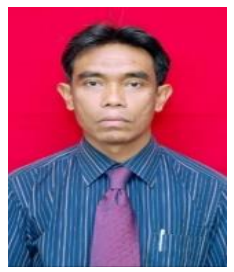

Ir. Syaifullah was born in Bukittinggi, on December 23,1966 . He is currently held position as senior manager of mining since 2017. Syaifullah is also a commissioner in Affiliation of Cement Tonasa Manufacturing since April 2019. He graduated from Mining Engineering Department of University of Sriwijaya - Palembang. Syaifullah has a lot of achievement as assessment board in many innovations and improvements related to Cement Industry. He is also selected as role model employee (Karyawan Teladan) in year of 2014. He is also put his very best concern regarding to biodiversity conservation, reclamation and land rehabilitation in post-mining activity.

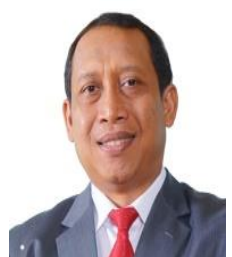

Ir. Bambang Haryanto was born in Tulung Agung, on April 30, 1967. He is currently production and operation director for Cement Tonasa Manufacturing. He has been joined Cement Tonasa Manufacturing since year of 1992. Haryanto graduated from Chemical Engineering Bachelor Degree Program of Institute Technology of Sepuluh Nopember - Surabaya. In year of 2017, Haryanto selected as role model employee and has been awarded a $25^{\text {th }}$ Years of Dedication in Cement Industry.

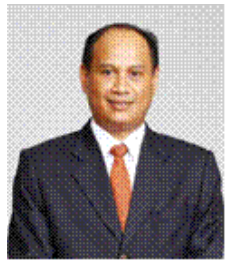

Subhan was born in Pallime - Bone, on May 12, 1971. $\mathrm{He}$ is currently president director of Cement Tonasa Manufacturing. He previously held position as Finance Director in the same industry, and has many experiences in financial expertise. Subhan graduated from Hasanuddin University - Makassar, both in bachelor and master degree. In year of 2017, Subhan has nationally awarded as The Best CEO for CSR from Corporate Forum Community Development and National Standardization Agency of Indonesia.

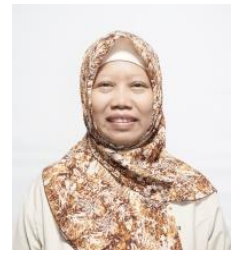

Ir. Sariatun was born in Surabaya, on July 20, 1967 Sariatun is currently General Manager of Production Planning and Control in Cement Tonasa Manufacturing. Sariatun has joined cement industry for decades, as previously positioned as genera manager of quality assurance and environment in the same company. Sariatun graduated from chemical engineering bachelor degree program of Institute Technology of Sepuluh Nopember - Surabaya, and master degree of management from Hasanuddin University - Makassar. Sariatun also experienced as one of Assessment Board of Gugus Kendali Mutu (Quality Control Truss) in Cement Tonasa from 2012 to 2014 